\title{
INTERNET AVAILABILITY AS AN INDICATOR OF PERIPHERALITY IN SLOVAKIA
}

\author{
Konštantín ROSINA, Pavol HURBÁNEK
}

\begin{abstract}
A method employing different data sources in the construction of indices that quantify internet availability is developed in this article, and it is applied at municipality and regional levels in Slovakia. The indices are subsequently correlated with other indicators commonly used to delineate peripheral areas, in order to evaluate factors which might influence (or be influenced by) the spatial distribution of internet availability. The results show that the information-communication technology side of spatial polarization generates similar patterns as the other more traditional aspects
\end{abstract}

\section{Shrnutí}

\section{Dostupnost internetu jako indikátor perifernosti na Slovensku}

Př́spěvek popisuje metodu, která využívá různé zdroje údajů pro tvorbu indexů kvantifikujících dostupnost internetu a aplikuje tuto metodu na úrovni obcí a regionů na Slovensku. Tyto indexy jsou následně podrobené korelační analýze ve vztahu $k$ jiným indexům obvykle používaných pro vymezení periferních území za účelem nalezení faktorů, které by potenciálně mohly ovlivnit (nebo být ovlivňované) prostorovým rozložením dostupnosti internetu. Výsledky ukazuji, že informačně-komunikační a technologický aspekt prostorové polarizace vytváří podobnou prostorovou strukturu jako jiné tradičně zkoumané aspekty.

Keywords: periphery, internet, broadband, information-communication technology, Slovakia

\section{Introduction}

\subsection{Approaches to delimitation of peripheries}

Landscape is an extremely complex, heterogeneous and dynamic system. The socio-economic sphere, in particular, with its typical nodal organization of space, is the source of heterogeneity at various spatial scales. This heterogeneity, often described as spatial polarization, is a fascinating and frequent object of research in many scientific disciplines.

Peripheries and cores are evident at multiple scales. Even one place can be a core at one scale and a periphery at another scale. Also, the same place can be seen as a periphery from one aspect (e.g. economic) and as a core from another aspect (e.g. ecological). The term peripheral is ambiguous as well. Some authors suggest that the terms peripheral and marginal are identical; others suggest that marginality is worse than peripherality (Andreoli, 2004). It is impossible to define a periphery universally; it can be done using only a certain approach or multiple approaches to the topic, but definitely not all of them. Leimgruber (1994) suggests four basic approaches to the delimitation of peripheries: (1) geometrical, which considers peripheries as areas on the geometrical periphery of a territory; (2) ecological, which can be understood either as a natural potential for human existence or as environmental quality; (3) economic, defining marginality on the bases of production potential, accessibility, infrastructure and attractiveness in terms of the spatial economy; and (4) social, focused on minorities and marginal social groups.

Some approaches employ various factors to delimitate specific types of peripheries. Havlíček et al. (2005) emphasize, that these factors and their intensity are changeable over time. Marada (2001) notes that physical-geographical factors (elevation, localization of natural resources) were primary factors influencing the distribution of core and peripheral regions; however, gradually social and economic factors gained on importance. While some authors focus on the influence of the former, most often georelief (e.g. Olah et al., 2006; Štych, 2011), others concentrate on the examination of the latter. Usually, only a few selected socio-economic factors are examined in a single study, most frequently transport accessibility alone (e.g. Horňák, 2006) by itself or in combination with settlement exposedness (e.g. Kabrda, 2004). A more synthesizing approach to 
the delineation of peripheral areas is less common. An example is the review by Halás (2008), taking into account a wide range of indicators divided into four groups: human resources, economic potential, personal amenities, and access to centres.

In fact, a whole set of peripherality attributes can be found, but they usually do not occur in their native forms, rather as results of complex inherent relations and influences. Usually, the following aspects can be recognized: a) physical-geographical (complexity of terrain, climate, elevation, etc.); b) geometric (distance from centre, location, etc.); c) economic (GDP per capita, unemployment, income, etc.); d) sociodemographic (education, age, gender, etc.); e) ecological (contamination, emissions, damage to forests, loss of biodiversity, etc.); f) cultural (ethnicity, local customs, etc.); g) religious; and h) political (degree of autonomy, administrative division, etc.) (Havlíček et al., 2005).

\subsection{Information-communication technology (ICT) and peripheries}

Geographic or human geographic disciplines often attempt to take a complex point of view on the topic and look for synthesizing indicators to delimitate the polarization of space. The development of a mobile telephone operator's coverage can be considered as an example of such an indicator. The operator takes into consideration a range of objective, but also subjective factors when deciding when and where to expand its network coverage (Havlíček and Chromý, 2001).

Linder et al. (2005) explicitly take the ICT perspective in the delimitation of peripheries in EU-15 countries. They use five groups of indicators in their analyses ICT, business networks, governance, social capital and tourism. The ICT group contains 22 indicators, e.g. cable modem/DSL connections, internet access prices, households with internet access, on-ine buyers, etc.

By analogy, we assume that the spread of internet infrastructure is spatially polarized, i.e. it is an innovation with spatial diffusion occurring over time. There is a lot of evidence about this in the research literature, for example, many American authors mention the rural-urban digital divide phenomenon, although we understand the development of ICT in the United States as being at least five years ahead of that in Slovakia).

Grubesic (2003) suggests that issues regarding the provision of residential broadband services are of great importance and that rural areas are currently lagging far behind urban areas in broadband availability in the United States. An example can be found in the state of Ohio where $46 \%$ of all counties have broadband digital subscriber line (DSL) service available in one or more locations. Of those counties classified as urban, 100\% have DSL service. For those counties considered rural, however, only $34 \%$ are equipped with DSL infrastructure. In addition, Grubesic examines characteristics of market demand that are driving cable and DSL infrastructure investment through the use of statistical models and a geographic information system. Results suggest that income, education, age, location, and competition from alternative broadband platforms influence DSL infrastructure investment.

The ICT revolution was associated with great expectations of positive consequences for the development of peripheries. The internet was supposed to become a powerful tool of decentralization, to compensate for the disadvantage of remote location, to enhance the quality of life, to enable the sustainable development of peripheries in a globalizing world, to slow down rural depopulation, etc. Even the term "death of distance" was coined (Cairncross, 1997) to describe the ability of the internet to substitute for transportation in some fields, e.g. e-commerce, e-learning, e-government, e-health and e-work. These expectations turned out to be exaggerated. Technological boom is a demanddriven process and the demand for new technologies is typically associated with densely populated urban areas usually with higher GDP per capita and younger and more educated populations than with peripheral areas having mostly the opposite characteristics.

While the peripheral rural areas, by their nature, have always suffered from serious infrastructural disadvantages, in terms of telecommunications infrastructure they have benefitted considerably in the past through cross-subsidization, resulting from the application of a universal service obligation by national telecommunications providers. With the liberalization of telecommunication markets in Europe and elsewhere in recent years, this is no longer the case, and with the shift towards more expensive broadband infrastructure being associated with a reliance on market forces, there is a real danger that the peripheral rural areas will become increasingly disconnected from the opportunities presented by the new digital economy (Grimes, 2003). This explains the difference between the narrowband access on the one hand, based on regular telephone lines that were provided as a "universal service" and therefore widespread in all areas, and the broadband access on the other hand, developing after liberalization of markets and therefore spreading only in areas where the laws of demand and supply applied. Although this does not mean that peripheries are completely disconnected, they are still lagging behind, with technologies at least one generation older than in central regions or with higher prices for comparable services. 
Some countries, however, have achieved remarkable success in spreading broadband into rural regions, especially the Scandinavian and Benelux countries. The reasons for the high level of broadband penetration in countries like Finland, even in their relatively remote rural regions, include the proactive involvement of their governments and the significance of the information technology in their economies (Henten and Kristensen, 2000). There are still quite large differences among the EU member states, though, especially between those mentioned above and those that joined the EU in this millennium (Fig. 1). Slovakia and Poland are the most lagging countries, especially in rural DSL coverage.

Involvement of the state seems to be the way to help the peripheral regions in the broadband take-up. EU institutions are aware of this and have approved action plans and initiatives focused on the problem. Apart from the Lisbon Strategy, which is a key document regarding the conception of an information society, a series of action plans (eEurope, eEurope 2002, eEurope+, eEurope 2005, i2010) has been approved.

The European Commission plan for the economic recovery of the EU includes a proposal to channel part of the unspent EU budget on broadband investment and announces the development of the EU broadband strategy in cooperation with member states and other relevant players. On 19-20 March 2009, the European Council approved the proposal for investment in broadband and a common agricultural

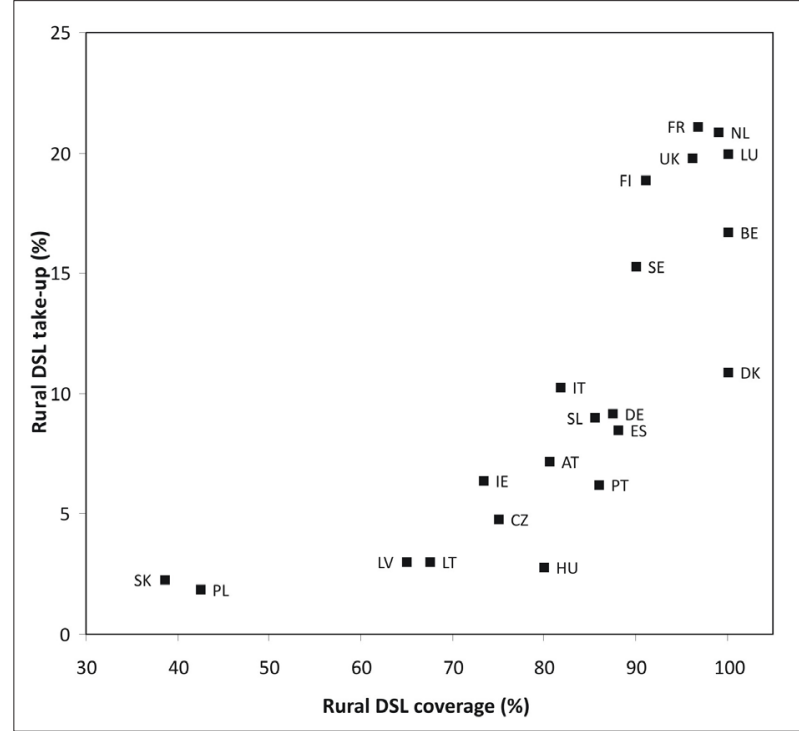

Fig. 1: DSL coverage in rural areas and share of population having a DSL internet subscription in rural areas in the EU countries, as of December 2007 (\%)

Note: Data for Bulgaria, Cyprus, Estonia, Greece, Malta and Romania are not available

Source: Directorate-General for Agriculture and Rural Development, 2008 policy health check ( $€ 1.02$ billion). A conference on the topic of the EU spending on broadband within the context of the recovery plan and the sharing of broadband good practices between rural and regional development authorities was held in Turin on 2-3 April 2009 (Regione Piemonte, 2009).

The United Kingdom is one of the EU countries with the best broadband availability in rural areas, more specifically with more than 90\% DSL coverage as of December 2007 (Fig. 1). In April 2009, the UK government signalled its commitment to ensuring everyone in the country has access to broadband speeds of two megabits per second by 2012 (BBC, 2009). In other words, the $2 \mathrm{Mbps}$ access should become a universal service.

\section{Methodology}

\subsection{Objectives}

The objectives of this paper are as follows: (1) to describe the method of collection, evaluation and quantification of data about availability of the internet, with a focus on residential broadband services; (2) to examine the spatial distribution of the phenomenon in Slovakia and to visualize it cartographically; and (3) to measure its correlation to other human- and physicalgeographical characteristics, which already have been used as criteria for the delimitation of peripheries.

\subsection{Availability versus penetration}

The "internetization" of society can be regarded from several points of view: as growth in the number of internet users, the number of subscribed households, the number of people covered by internet services, internet usage in public administration, the importance of on-line services, etc. Usually, two indicators (based on two of the above-mentioned aspects) are used to evaluate and compare the level of internetization:

1. The share of households or population that subscribe(s) to an internet service provider (ISP) and also use(s) its service is often referred to as the penetration (or simply take-up) of the internet. This indicator designates real customers of internet services and therefore it is more immediate or direct in nature (as opposed to the next one that could be regarded as less immediate or indirect) and thus - in a sense - is also more objective. However, its disadvantage is the availability of statistical data. In Slovakia, for example, these data are available only for the NUTS 3 regions and thus are not suitable for the assessment of spatial distributions assessment at a finer scale of resolution.

2. The availability of internet can be defined as a share of population/households being covered by 
ISP services, i.e. coverage. It is also adequate to consider differences in the quality or number of available services.

Values of both mentioned indicators (considering only DSL services) for EU countries are displayed in Fig. 1. As the availability of a service is a primary premise to a customer's decision to subscribe to it, it is not a surprise that these two indicators are positively related. The other factors that influence the decision include for example the ownership of a computer or another connectable device, computer literacy, knowledge of the advantages of the internet, ability and willingness to bear the costs of subscription, etc. The survey of 4,500 households conducted in Slovakia in the second quarter of 2007 identified the following reasons for not subscribing to an internet service connection: "We do not want or do not need the internet" (48\%); "We have access to the internet elsewhere" (31\%); "The installation of the internet is too expensive" (27\%); "The use of the internet is too expensive" (31\%); and "I can not work with the internet" (19\%) (Statistical Office of the Slovak Republic, 2007).

\subsection{Study area}

The entire territory of Slovakia was examined using two systems of spatial units representing two different hierarchical levels or spatial resolution scales: Firstly, 2,928 LAU 2 units, which include 2,889 municipalities, 17 parts of the Bratislava City, and 22 parts of the Košice City, hereinafter referred to as municipalities, were determined. A second set of 49 quasi-functional urban regions (QFURs) was created by the aggregation of 79 existing districts (LAU 1 units), which is a frequently-used approximation to real functional urban regions called "System FMR 91A" developed by Bezák (2000) that gives the possibility of using statistical data available for districts.

\subsection{Data collection}

The variety and nature of internet availability means is a limiting factor with respect to data collection. There is a great number of providers of internet access including the local and regional ones (several hundred ISPs), and therefore there is no unified data source. It is almost impossible to evaluate all of them, as many of the local ISPs do not provide information about the spatial availability of their networks. Another issue concerns the variability of the attributes of connection technologies - bandwidth, price, mobility, data transfer limits, etc. It is obvious that the problem has to be handled with some degree of generalization.

Using a method developed by Rosina (2008), eight of the most significant broadband technologies of connection (as they were available in the first half of 2008) were taken into account. With the internet coverage considered as an innovation spatially diffusing in time, the choice of and the focus on broadband technologies and their availability level at the given moment in time was crucial with respect to its application as a synthesizing indicator of peripherality. Four of the eight technologies were fixed wired (ADSL, ADSL2+, CaTV, FTTH), two were fixed wireless (WiFi, WiMax) and two were mobile wireless (HSPA, FLASH-OFDM). Basically, two types of data sources regarding availability were used - [a] online maps of coverage (HSPA, FLASH-OFDM, WiMax) or $[b]$ a simple listing of municipalities, where services are available (the five other technologies). The rate of availability of each of the technologies was identified in each of the municipalities. A value of the variable $r a_{t}$ (rate of availability of technology $t$ ) was determined in two different ways. The variables $r a b_{t}$, the rates of availability of technologies with data source $[b]$, were set to binary values, 0 if the technology is not and 1 if it is available. The variables $r a a_{t}$, the rates of availability of technologies with data source [a], were set to values from the interval $\langle 0,1\rangle$ bounded and closed from both sides, representing the share of built-up areas of a municipality covered by the technology and - if making the assumption of anevenly distributed population in the built-up area - also the share of population of a municipality covered by the technology.

Although this is an unrealistic assumption, it is much more realistic than what is often being done when trying to derive covered population size by overlaying service coverage maps with traditional population density choropleth maps or population count proportional symbol thematic maps (see e.g. Kusendová and Bačík, 2009 for more details on advantages and disadvantages of different types of thematic maps). Before overlaying the coverage areas of the individual technologies with the layer of built-up areas (ÚGKK SR, 2005) based on 1:50000 map, this layer had to be modified (as illustrated in Fig. 2) in order to reduce some spatially exaggerated objects on the original map, e.g. roads (see also Hurbánek, 2008).

\section{Results}

\subsection{Construction of synthesizing indicators}

Two pairs of slightly different synthesizing indicators of the internet availability (one simple and one weighted for both municipalities as well as QFURs) were constructed by combining eight $r a_{t}$ values derived in the previous step. The first pair of indicators is based on a simple arithmetic mean of the $r a_{t}$ values. The second pair of indicators is based on a weighted mean of the $r a_{t}$ values, where the weights are calculated as a bandwidth-to-price ratio of each technology (Fig. 3). 


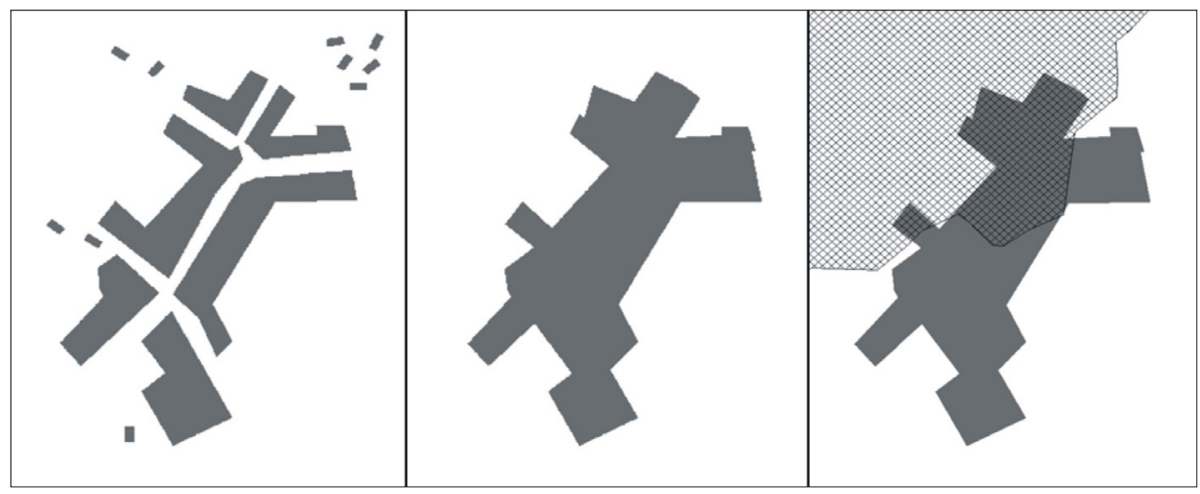

Fig. 2: Modification of built-up areas layer

$$
A S_{m}=\frac{\sum_{t=1}^{8} r a_{t m}}{8} A W_{m}=\frac{\sum_{t=1}^{8}\left(r a_{t m} w_{t}\right)}{\sum_{t=1}^{8} w_{t}} A S_{q}=\frac{\sum_{m=1}^{n}\left(A S_{m} P_{m}\right)}{\sum_{m=1}^{n} P_{m}} A W_{q}=\frac{\sum_{m=1}^{n}\left(A W_{m} P_{m}\right)}{\sum_{m=1}^{n} P_{m}}
$$

Fig. 3: Internet availability indicators $\left(A S_{m}\right.$ - internet availability rate in municipality $m$ (simple); $A W_{m}-$ internet availability rate in municipality $m$ (weighted); $A S_{q}$ - internet availability rate in QFUR $q$ (simple); $A W_{q}-$ internet availability rate in QFUR $q$ (weighted); rat ${ }_{m}$ - rate of availability of technology $t$ in municipality $m$; $w_{t}-$ weight of technology $t ; P_{m}$ - population of municipality $m ; n$ - number of municipalities in QFUR)

By calculating a mean of eight $r a_{t}$ values of two types of variables according to the scale of measurement (binary $r a b_{t}$ values and ratio $r a a_{t}$ values) the resulting $A S_{m}$ value from the interval $\langle 0,1\rangle$ bounded and closed from both sides is essentially a weighted mean of two proportions: (1) the proportion of the technologies available in a given municipality from all the studied type-[b] technologies (with weight $=5$ ), and (2) the average proportion of the built-up area (and also of the population, if the builtup area is assumed to be homogenous with respect to population density) in a given municipality covered by the type-[a] technologies (with weight $=3$ ).

Fig. 4 shows the spatial distribution of the $A S_{m}$ values. Fig. 5 shows the spatial distribution of the SUMD 300 values, which is an indicator that represents the sum of direct distances (beelines) from the given municipality to the closest of the $1,2,3$, ... 300 largest (in terms of population) municipalities (Džupinová et al., 2008). The patterns formed by these two indicators representing two different aspects of peripherality are notably similar.

\subsection{Correlation analysis}

The four synthesizing indicators were analysed together with a set of other peripherality indicators. When selecting the latter indicators, a wider range of them was preferred, so that as many of potential significant relations as possible could be revealed. All basic approaches to the delimitation of peripheries were considered in the selection of indicators (geometric, ecological, economic and social). Finally, a set of 31 indicators was used in the analysis for QFURs and 12 variables for municipalities, using Pearson's, Kendall's and Spearman's correlation coefficients.

The analysis revealed statistically significant correlations (at $\alpha=0.01$ ) between the synthesizing indicators and some of the other peripherality indicators. While in some cases it is the $A S$ indicator that yields stronger correlations, in others it is the $A W$ indicator. At the municipality level, six indicators correlated with the $A S_{m}$ or $A W_{m}$ indicator obtained Pearson's $r$ values between (+ or -) 0.70 and 0.43 (in descending order):

- The above-mentioned SUMD 300 indicator;

- Share of households with the internet connection according to the 2001 census;

- Mean number of schooling years (SCHOOL) assuming the following numbers of years spent attending school by inhabitants at different highest achieved levels of education according to the 2001 census: primary 8.5, secondary without final exam 11.5, secondary with final exam 12.5, "higher" 14.5, Bachelor level 15.5, Master level 17.5, Ph.D. level 20.5;

- Population size as of 31 December 2006;

- Population density per $1 \mathrm{~km}^{2}$ of built-up area as of 31 December 2006; and

- Population density per $1 \mathrm{~km}^{2}$ as of 31 December 2006 (DENSITY).

As the scatter plots revealed some nonlinear relationships, it is worth noting that after simple mathematical transformations of some of the variables 


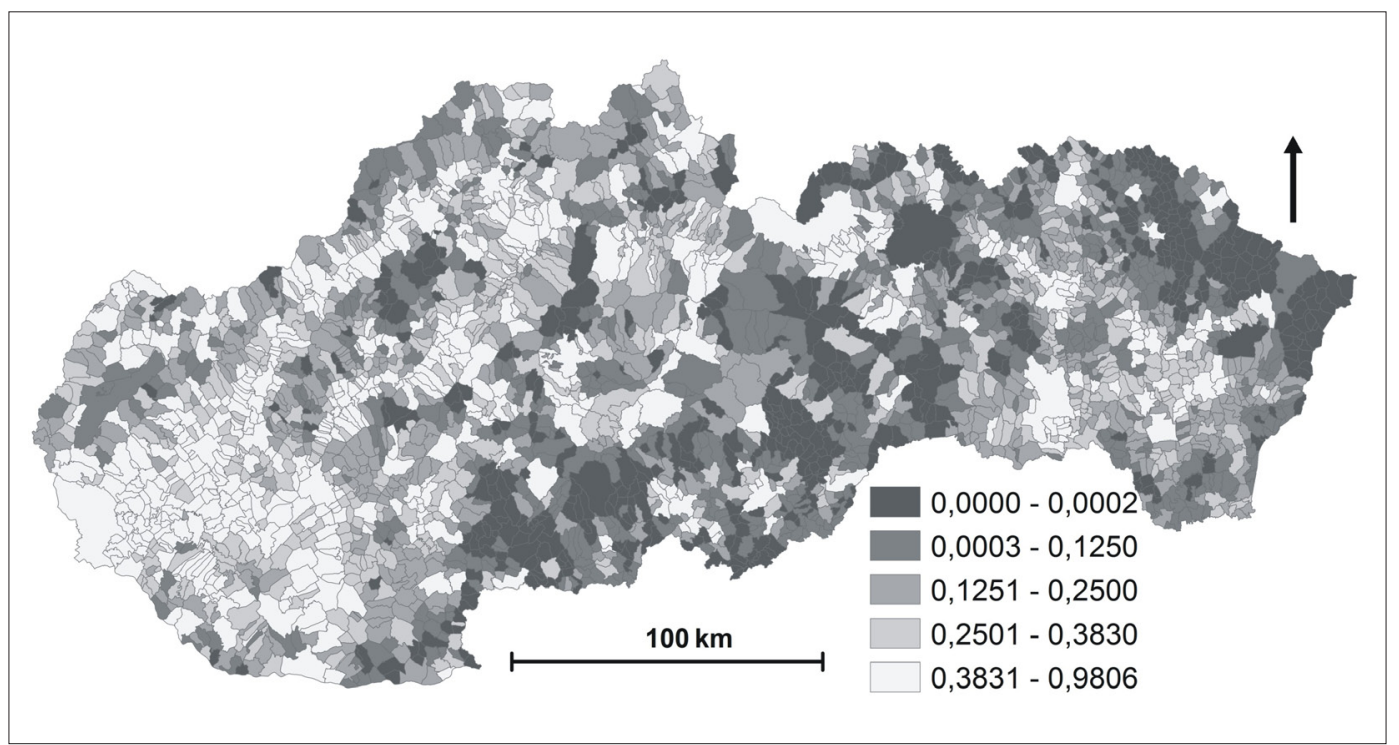

Fig. 4: Internet availability rate in municipalities ASm (proportions) in Slovakia classified into quintiles Note: the inverse colour scheme enhancing the comparability with Fig. 5

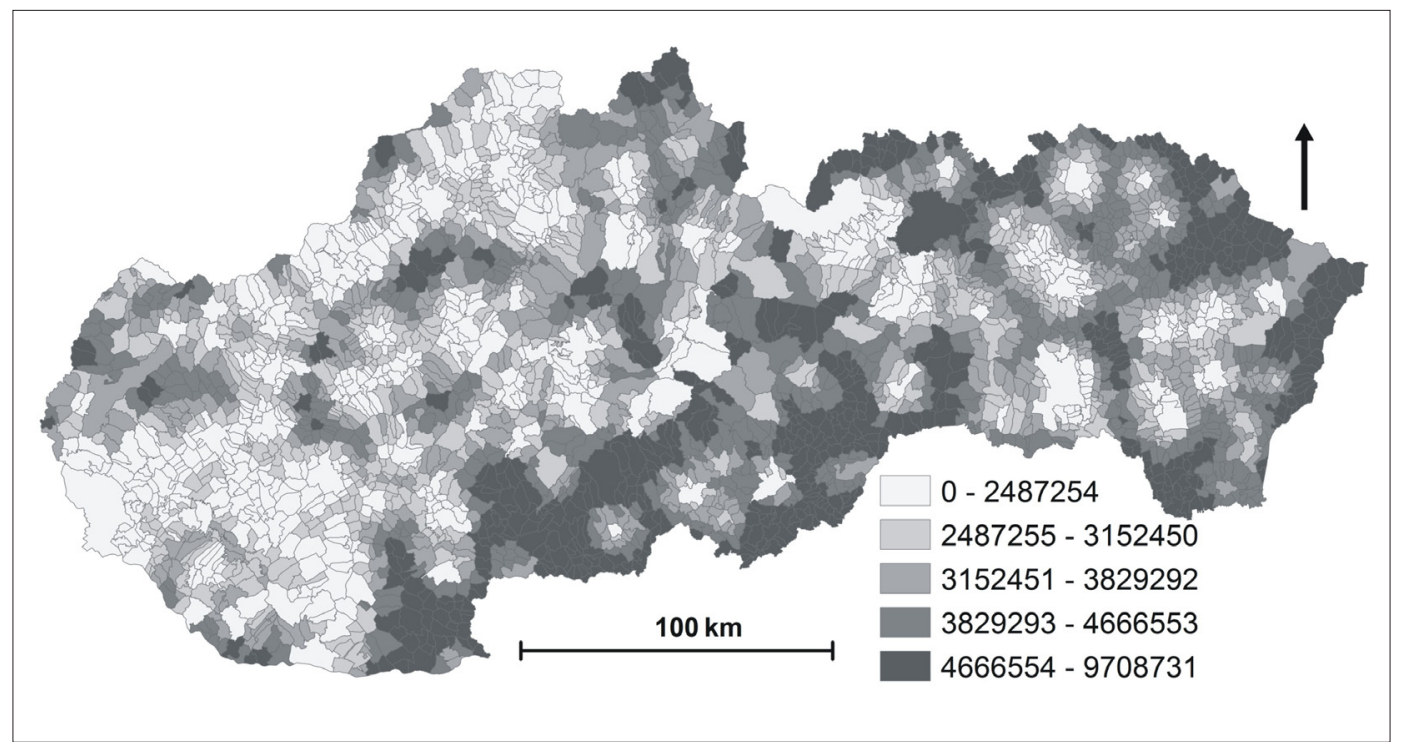

Fig. 5: Sum of the distances in municipalities SUMD 300 (metres) in Slovakia classified into quintiles

even greater absolute values of the respective Pearson's correlation coefficients are found. This is in accordance with the fact that the top four most correlated variables with either $A S_{m}$ or $A W_{m}$ indicator - when measured by Kendall's and Spearman's correlation coefficients are slightly different (in descending order):

- The above-mentioned SUMD 300 indicator;

- Population density per $1 \mathrm{~km}^{2}$ as of 31 December 2006 (DENSITY);

- Population size as of 31 December 2006; and

- Mean number of schooling years (SCHOOL).

Obviously, the correlations at the QFUR level turned out to be generally stronger than those at the municipality level. At the QFUR level, 17 indicators correlated with the $A S_{q}$ or $A W_{q}$ indicator reached Pearson's $\mathrm{r}$ values between (+ or -) 0.86 and 0.55 .
Seven of them showed the highest correlation with $\mathrm{r}$ values between (+ or -) 0.86 and 0.77 (in descending order):

- The mean value (weighted by municipality population) of the above-mentioned SUMD 300 indicator within given QFUR;

- Population density per $1 \mathrm{~km}^{2}$ as of 31 December 2006 (DENSITY);

- Share of households with the internet connection according to the 2001 census;

- Mean number of schooling years (SCHOOL);

- Economic aggregate (mean monthly income multiplied by the number of employed persons) per capita in 2006;

- The mean of the shares of households with water, gas and sewage systems connections, each of them representing a different stage of innovation 
diffusion in time in Slovakia with the shares of $95.1 \%, 74.5 \%$ and $56.5 \%$ in the given order according to the 2001 census; and

- Mean monthly income of an employee in organisations with more than 20 employees in 2006 (INCOME).

Figure 6 shows some example scatter plots for some of these relations (see also Rosina, 2008; Džupinová et al., 2008).

\section{Conclusion}

The construction of indicators made it possible to visualize and explore the spatial distribution of internet availability in Slovakia and to evaluate related and potentially influencing and/or influenced spatial, ecological, economic and social factors by means of correlation analysis. This helped to identify a whole range of areas from those with an excellent service to those with a very poor one. Results of the correlation analysis show the relation of the specific attributes of space, society and economy to spatial variations in internet availability, and they also suggest that the internet availability might be used as an appropriate synthesizing indicator of peripherality, at least in the conditions of Slovakia in the middle of the current decade. Because strong relationships have been found between internet availability on the one hand and most of the geometric and some economic and sociodemographic periphery indicators on the other hand, it is clear that the internet availability has not brought about the "death of distance" yet, but rather has followed and accentuated the existing polarized socioeconomic spatial structure.

Obviously, there are many different ways, in which this research work could be further developed, for example by collecting new data on the ever-expanding internet coverage; by analysing the dynamics of the diffusion process; or by employing more sophisticated multivariate analyses to achieve a better understanding of the mutual relationships amongst all the considered peripherality indicators. Nevertheless, since one of the objectives of this paper was to point out the importance of accounting for the share of the municipality built-up area instead of the share of the municipality total area covered by the service in focus, a logical next step - from

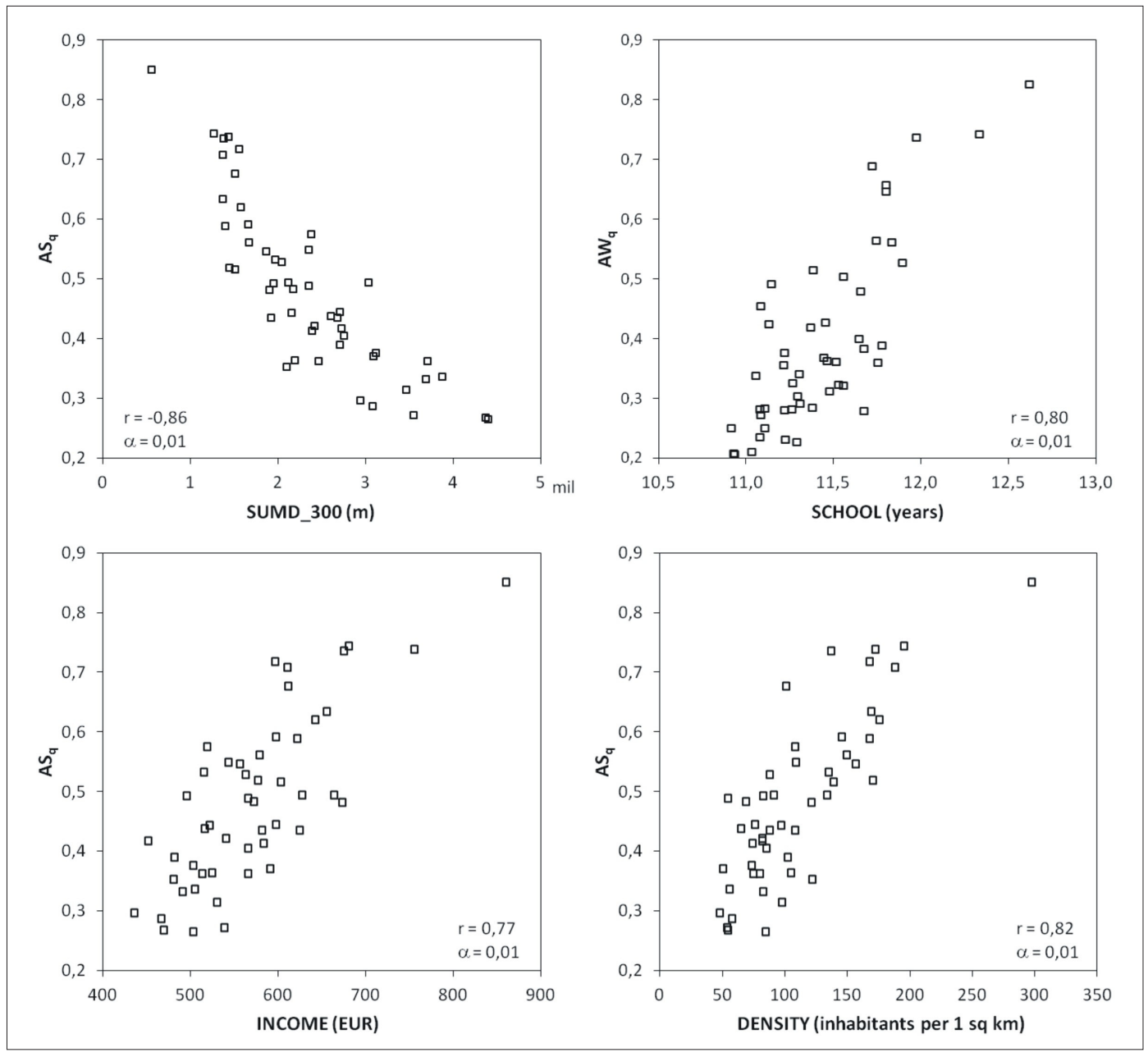

Fig. 6: Part of the results for QFUR 
the geographical research point of view - is rejection of the assumption that the built-up area in the given municipality is populated at homogenous density. This or similar assumptions have been implicitly present in and thus hindering the geographical research for ages. However, with the development of geoinformation technology and new data sources emerging on the horizon, the datasets such as high resolution population rasters for whole countries and continents are becoming increasingly available. What seems to be an obvious thing to do next step is to use these datasets and turn them into instruments that would take the geographical research over the hindrance of this unrealistic assumption to the next level.

\section{Acknowledgement}

This research was supported by the Slovak Scientific Grant Agency VEGA project No. 1/0275/13 "Production, verification and application of population and settlement spatial models based on European land monitoring services".

\section{References:}

ANDREOLI, M. (1994): Development and marginalization in Liguria region. In: Chang-Yi, D. Ch., Sue Ching, J., Yin-Yuh, L. [eds.]: Marginality and development issues in marginal regions, Proceedings, 1-7 August 1993. Taiwan, National Taiwan University and International Geographic Union, p. 41-61.

BBC (2009): Government backs 2Mbps broadband. [online]. BBC News [cit. 7.10.2012]. Available at: URL: <http://news.bbc. co.uk/2/hi/technology/8012848.stm>.

BEZÁK, A. (2000): Funkčné mestské regióny na Slovensku. Geographia Slovaca, Vol. 15, p. 1-90.

CAIRNCROSS, F. (1997): The Death of Distance: How the Communications Revolution Will Change Our Lives. Boston, Harvard Business School, 303 pp.

DIRECTORATE-GENERAL FOR AGRICULTURE AND RURAL DEVELOPMENT (2008): Rural Development in the European Union. Statistical and Economic Information - Report 2008. [online]. EU DG AGRI [cit. 7.10.2012]. Available at: URL: <http://ec.europa.eu/agriculture/agrista/rurdev2008/RD_Report_2008.pdf> .

DŽUPINOVÁ, E., HALÁS, M., HORŇÁK, M., HURBÁNEK, P., KÁČEROVÁ, M., MICHNIAK, D., ONDOŠ, S., ROCHOVSKÁ, A. (2008): Periférnost a priestorová polarizácia na území Slovenska. Bratislava, Geo-grafika, 186 pp.

GRIMES, S. (2003): The digital economy challenge facing peripheral rural areas. Progress in Human Geography, Vol. 27, No. 2, p. 174-193.

GRUBESIC, T. H. (2003): Inequities in the broadband revolution. The Annals of Regional Science, Vol. 37, No. 2, p. 263-289.

HALÁS, M. (2008): Priestorová polarizácia spoločnosti s detailným pohladom na periférne regióny Slovenska. Sociologický časopis/Czech Sociological Review, Vol. 44, No. 2, p. 349-369.

HAVLÍČEK, T., CHROMÝ, P. (2001): Př́́spěvek k teorii plarizovaného vývoje území se zaměřením na periferní oblasti. Geografie - sborník České geograické společnosti, Vol. 106, No. 1, p. 1-11.

HAVLÍČEK, T., CHROMÝ, P., JANČÁK, V., MARADA, M. (2005): Vybrané teoreticko-metodologické aspekty a trendy geografického výzkumu periferních oblastí. In: Novotná, M. [ed.]: Problémy periferních oblastí. Praha, Univerzita Karlova v Praze, Př́rodovědecká fakulta, Katedra sociální geografie a regionálního rozvoje, p. 6-24.

HENTEN, A., KRISTENSEN, T. M. (2000): Information society visions in the Nordic countries. Telematics and Informatics, Vol. 17, p. 77-103.

HURBÁNEK, P. (2008): Recent developments in definitions of rurality/urbanity: Focus on spatial aspect and land cover composition and configuration. In: Europa XXI, Vol. 17, Warszawa, Polish Academy of Sciences, Stanisław Leszczycki Institute of Geography and Spatial Organization, p. 9-27.

HORŇÁK, M. (2006): Identification of regions of transport marginality in Slovakia. Europa XXI, Vol. 15, Warszawa, Polish Academy of Sciences, Stanisław Leszczycki Institute of Geography and Spatial Organization, p. 35-41.

KABRDA. J. (2004): Vliv polohové exponovanosti na rozložení využití ploch v kraji Vysočina. Geografie - sborník České geograické společnosti, Vol. 109, No. 3, p. 223-235.

KUSENDOVÁ, D., BAČÍK, V. (2009): Počítačová tvorba tematických máp - Cvičenia v MapInfo Professional (2. rozšsírené vydanie). Bratislava, Geo-grafika, $160 \mathrm{pp}$.

LEIMGRUBER, W. (1994): Marginality and marginal regions: problems of definition. In: Chang-Yi, D. C., Sue Ching, J., YinYuh, L. [eds.]: Marginality and development issues in marginal regions, Proceedings, 1-7 August 1993. Taiwan, National Taiwan University and International Geographic Union, p. 1-18.

LINDNER, Ch. et al. (2005): A spatial Peripherality in Europe. Cartographic and statistical analyses. Dortmund, Universität Dortmund, Institut für Raumplanung, 86 pp. 
MARADA, M. (2001): Vymezení periferních oblastí Česka a studium jejich znaků pomocí statistické analýzy. Geografie sborník České geograické společnosti, Vol. 106, No. 1, p. 12-25.

OLAH, B., BOLTIŽIAR, M., PETROVIČ, F. (2006): Land use changes' relation to georelief and distance in the East Carpathians Biosphere Reserve. Ekológia Bratislava, Vol. 25, No. 1, p. 68-81.

REGIONE PIEMONTE (2009): European Regions for better ICT connections, Conference Turin 2-3.4.2009. [online]. Direzione Regionale 21 - Innovazione, Ricerca, Università e Sviluppo Energetico Sostenibile [cit. 7.10.2012]. Available at: URL: http://www.regione.piemonte.it/innovazione/regions4ict.html.

ROSINA, K. (2008): Dostupnost' internetu v SR a jej vztah k periférnosti územia. Bakalárska práca. Bratislava, Univerzita Komenského v Bratislave, Prírodovedecká fakulta, Katedra regionálnej geografie, ochrany a plánovania krajiny, 50 pp.

STATISTICAL OFFICE OF THE SLOVAK REPUBLIC (2007): Informácia o výsledkoch zistovania o využívaní IKT v domácnostiach. [online]. ŠÚ SR [cit. 4.7.2008]. Available at: URL: http://portal.statistics.sk/showdoc.do?docid=8874.

ŠTYCH, P. (2011): Comparative analysis of the impact of slope inclination and altitude on long-term land use changes in Czechia. Acta Universitatis Carolinae, Geographica, Vol. 46, No. 1, p. 71-76.

ÚGKK SR (2005): Continuous Vector Map SVM 50 (084/051108-AG). Bratislava, Institute of Geodesy, Cartography and Cadastre of the Slovak Republic.

\section{Authors addresses:}

Mgr. Konštantín ROSINA

Slovak Academy of Sciences, Institute of Geography

Štefánikova 49, 81473 Bratislava, Slovakia

e mail: konstantin.rosina@gmail.com

Mgr. Pavol HURBÁNEK, Ph.D.

Catholic University in Ružomberok, Faculty of Education, Geography Department

Hrabovská cesta 1, 03401 Ružomberok, Slovakia

e mail: pavolhurbanek@gmail.com

Initial submission 23 October 2012, final acceptance 15 March, 2013

Please cite this article as:

ROSINA, K., HURBÁNEK, P. (2013): Internet Availability as an Indicator of Peripherality in Slovakia. Moravian Geographical Reports, Vol. 21, No. 1, p. 16-24. 